\title{
MICRONUCLEUS ASSAY IN ENVIRONMENTAL BIOMONITORING
}

\author{
Michalová, V., Galdíková, M., Holečková, B. \\ Koleničová, S., Schwarzbacherová, V.* \\ Institute of Genetics, University of Veterinary Medicine and Pharmacy in Košice \\ Komenského 73, 04181 Košice \\ Slovakia
}

*vierka.kolesarova@gmail.com

\begin{abstract}
Nowadays many chemicals are widely used in agriculture to ensure high crop yields or in veterinary/human medicine to cure diseases. After their improper usage they may contaminate the environment, persist in it and adversely affect both the target and/or the nontarget organisms. One of the ways to detect the occurrence of chemicals in the environment is to assess their impact on aquatic and farm animals; both are directly or indirectly exposed via their feed and water. The micronucleus assay is a standardly used cytogenetic test for the simultaneous detection of clastogenic and aneugenic agents. Additionally, cytotoxic effects are also assessed by analysing the proliferation changes using the cytokinesis-blocked proliferation index. The occurrence of micronuclei is analysed in many types of cells like the peripheral blood cells, bone marrow or cell lines according to standards for micronuclei detection. The analysis of published results has shown that the micronucleus assay is, together with the chromosomal aberration test, one of the most often used test in genotoxicity assessment.
\end{abstract}

Its results have contributed to reassessing the use of multiple chemicals available on the market. Moreover, it is a compulsory test before approving the chemical/ pesticide for the market.

Key words: biomarker; cytotoxicity; genotoxicity; micronucleus; pesticide

\section{INTRODUCTION}

Micronuclei (MNs) are small, extranuclear chromatin corpuscles surrounded by a nuclear coat. They originate from acentric chromosomes or their fragments, that are lagging behind karyokinesis in anaphase and they are not part of the daughter nuclei at telophase $[14,23]$. In 1959, for the first time, Ev a n s et al. [12] described the use of $\mathrm{MNs}$ as biomarkers of DNA damage of the root tips of $\mathrm{Vi}$ cia faba when the cytogenetic effects of neutrons (cobalt-60 gama-radiation and by fast neutrons) were tested.

In general, the presence of $\mathrm{MN}$ seems to serve as a signal for elimination. There are four possible ways of mi- 
cronuclei elimination: degradation, reincorporation into the main nucleus, extrusion from the cell, and persistence in the cytoplasm; but there are two additional fates: the premature chromosome condensation/chromothripsis and the elimination of MN cells by apoptosis [23]. The degradation of MN was observed under specific situations in fixed primary and immortalized cells from humans and other animal species. Those MNs were induced by clastogenic/ aneugenic agents and the type of degradation was variable (apoptic, autophagic, lysosomal). Autophagy represents one way of micronuclei degradation. It is a catabolic process when degradation of cellular components is caused by lysosomes [11]. Another possible fate of micronuclei degradation has been described by Rello-V a r o n a et al. [37]. The authors found that MNs were removed by macroautophagy. A small percentage of MNs was localized inside autophagic vesicles and the collapse of the $\mathrm{MN}$ envelope observed could have been associated with DNA damage caused by those lysosomes. Then, the extrusion of the MNs has only been shown under very specific experimental circumstances; the MN can be extruded during a high concentrated cytoB-induced anucleation observed in mammalian cells [30] and/or micronuclei containing whole chromosomes can be extruded [39]. Then, chromotripsis (premature chromosome condensation) can occur. It causes massive genomic rearrangements resulting in the presence of highly mutated chromosomes within one cell cycle. A higher percentage of reincorporation was observed in MNs induced by aneugenic agents, but data from studies are not consistent, so general conclusions cannot be made. On the other hand, a very high percentage of MNs persists until the next mitosis without alteration [23].

The cytokinesis-block micronucleus assay (CBMN) is preferred using both in vivo and in vitro methods of MNs detection in various cell lines [14]. The author described the CBMN cytome assay as the comprehensive system for measuring DNA damage, cytostatic and cytotoxicity, where specifically once divided binucleated $(\mathrm{BN})$ cells were scored. The occurrence of the MN (biomarker of chromosomal breakage and/or loss of whole chromosome), nucleoplasmatic bridges (NPB, biomarker of faulty DNA repair and/or telomere and fusion), nuclear buds (NB, biomarker of elimination of amplified DNA and/or complex DNA repair mechanism) are analysed. Moreover, the cytostatic effects are scored using the cytokinesis-blocked proliferation index (CBPI) which is the ratio between mono-, bi- and multinucleated cells and cytotoxic effects through the ratio of the necrotic and/or apoptotic cells.

The CBMN is used for monitoring of clastogenic (mainly induction of chromosomal fragments) and aneugenic (disruption of mitotic apparatus leading to mis-segregation either chromatids or whole chromosomes during mitosis) effects of the chemical agents as genotoxic damage. The MNs are also widely used as indicators of genomic instability and in vivo exposures by genotoxins in biomonitoring studies [23].

In this review we will summarize information and make conclusions whether the CBMN test is a suitable method for in vivo or in vitro genotoxicity testing in aquatic species and farm animals.

\section{MATERIALS AND METHODS}

The data were obtained by the analysis of previously published research involving methodology and analysis of the micronucleus assay and its application to genotoxicology assessment in water environments and farm animals. The authors "experiences" in the application of MN assay on bovine peripheral lymphocytes were also described and analysed in the article.

\section{COMPARISON OF IN VITRO AND IN VIVO MICRONUCLEUS TEST}

According to the OECD guidelines, the following two main types of MN assays are approved for chemical testing: the in vivo mammalian erythrocyte $\mathrm{MN}$ assay (OECD No. 474) [31] and the in vitro mammalian micronucleus test (OECD No. 487) [32]. Their summary and comparison can be found in Table 1 .

\section{SLIDE SCORING AND ANALYSIS}

The criteria for scoring cells has been described in detail in the HUMN project [15] and CBMN cytome assay [14], and are used as standards for scoring the cells.

The microscopic analysis of each slide should be performed by two different scorers using identical microscopes and examining at $1000 \times$ magnification. The sam- 


\begin{tabular}{|c|c|c|}
\hline & In vivo mammalian erythrocyte $\mathrm{MN}$ test & In vitro mammalian cell $\mathrm{MN}$ test \\
\hline Experimental models & mice, rats, other mammalian species & human, rodents \\
\hline Samples & bone marrow, peripheral blood & peripheral blood cells-lymphocytes, cell lines \\
\hline Solvents & $\begin{array}{l}\text { water, physiological saline, methylcellulose solution, } \\
\text { olive oil, corn oil }\end{array}$ & $\begin{array}{l}\text { water, physiological saline, dimethyl sulfoxide (dmso), } \\
\text { ethanol, acetone }\end{array}$ \\
\hline Positive controls & $\begin{array}{l}\text { ethyl methanesulphonate, methyl methanesulphonate, } \\
\text { ethyl nitrosourea, mitomycin c, cyclophosphamide, } \\
\text { triethylenemalamine, colchicines, viriblastine }\end{array}$ & $\begin{array}{l}\text { methyl methanesulphonate, mitomycin c, 4-nitroquin- } \\
\text { oline-n-oxide, cytosine arabinoside, benzo(a)pyrene, } \\
\text { cyclophosphamide, colchicines, viriblastine }\end{array}$ \\
\hline $\begin{array}{l}\text { Preparation of } \\
\text { samples }\end{array}$ & $\begin{array}{l}\text { bone marrow cells-humane euthanasia (femurs, tibias), } \\
\text { peripheral blood - from tail vein or other blood vessel, } \\
\text { cardiac puncture or large vessel }\end{array}$ & $\begin{array}{l}\text { cell lines - harvested in culture medium, lymphocytes } \\
\text { need mitogen stimulation (e.g. phytohaemagglutinin), } \\
\text { with or without cytochalasin-b }\end{array}$ \\
\hline $\begin{array}{l}\text { Preparation } \\
\text { for staining }\end{array}$ & $\begin{array}{l}\text { stained for microscope (giemsa), fixed for flow cytom- } \\
\text { etry (acridine orange/ hoechst } 33258+\text { pyronin-y) }\end{array}$ & giemsa, acridine orange, hoechst $33258+$ pyronin-y \\
\hline Analysis/scoring cells & $\begin{array}{l}\text { randomised manual evaluation (by microscope), } \\
\text { automated systems (flow cytometrs, image analysis } \\
\text { platforms, laser scanning cytometers) }\end{array}$ & $\begin{array}{l}\text { by microscope or automated scoring systems (flow } \\
\text { cytometry, laser scanning cytometry, image analysis) }\end{array}$ \\
\hline
\end{tabular}

ples should be ideally obtained and assessed from duplicate cultures. At first, the frequency of mono-, bi- and multinucleated viable cells, as well as apoptotic and necrotic in a minimum are analysed for each slide. Then the occurrences of micronuclei, nuclear bridges and buds are detected. The following data gives us: information about the nuclear division index/cytokinesis-block proliferation index, the number of apoptotic cells per 500 cells, the number of necrotic cells per 500 cells, and the frequency of BN cells containing MN, NPB, NB in at least $1000 \mathrm{BN}$ cells $[14,15]$.

Nuclear division index (NDI) measures the proliferative status of the viable cell fraction,

$$
\mathrm{NDI}=\left(1 \times \mathrm{M}_{1}+2 \times \mathrm{M}_{2}+3 \times \mathrm{M}_{3}+4 \times \mathrm{M}_{4}\right) / \mathrm{N}
$$

where

M1-M4 represent the number of cells with $1-4$ nuclei and $\mathrm{N}$ is the total number of viable cells scored (excluding necrotic and apoptotic cells). The NDI is a useful parameter for comparing the mitotic division of lymphocytes and cytostatic effects of agents examined in the assay.

Cytokinesis-block proliferation index (CBPI) is calculated according to S u r rallé s et al. [45] for the cell cycle delay and/or cytotoxicity induced by chemical agents,

$$
\mathrm{CBPI}=\left[1 \times \mathrm{M}_{1}+2 \times \mathrm{M}_{2}+3 \times\left(\mathrm{M}_{3}+\mathrm{M}_{4}\right)\right] / \mathrm{n}
$$

where

M1-M4 represent the number of cells with $1-4 \mathrm{nu}-$ clei and $\mathrm{n}$ is the total number of scored cells.

Both NDI and CBPI reflect the dose dependency of cytotoxicity more accurately than only the percentage of $\mathrm{BN}$ cells do. The CBPI is similar to the NDI, expect that the NDI estimates the average number of nuclei per cell. The CBPI indicates the average number of cell cycles undergone by a given cell, which may be more relevant in the case of cytokinesis/blocked cells. The CBPI classifies both trinucleated and tetranucleated cells into the same category and equally considered being in their third cell cycle [45].

The anticipated results depend on several factors like: the culture conditions, level of exposure to genotoxic or cytotoxic agents and their potency, the composition of the medium, the genetic background, and the age and gender of the donor of the cells. For normal peripheral human blood lymphocytes, F e n e ch [14] assumed the following range of values: $30-60 \%$ of BN cells; NDI: $1.3-2.2,0-9 \%$ of necrotic cells; $0-7 \%$ of apoptotic cells; and $0-30$ of $\mathrm{MNi}$, $0-10 \mathrm{NPBs}$ and $0-5$ NBUDs per 1,000 BN cells, respectively.

According to the OECD protocol no. 474 for in vivo eryMN (erythrocyte micronucleus) test, all slides and samples for analysis should be scored according to its standards. The ratio among immature and total eryth- 
rocytes (ery) should be determined for each animal by counting at least 500 erythrocytes from bone marrow and 2000 erythrocytes from the peripheral blood. Then, the incidence of the micronucleated immature erythrocytes should be scored in at least 4000 immature erythrocytes per animal [31].

For the in vitro cell $\mathrm{MN}$ test, it is recommended to score the cytokinesis-block proliferation index (CBPI) and/or Replication Index (RI) from at least 500 cells per culture to determine the cell proliferation and the cytotoxic and/ or cytostatic activity using cytochalasin-B. Besides those, we can estimate other indicators of cytotoxicity, such as cell integrity, apoptosis, necrosis, metaphase counting, and the cell cycle. In test studies without cytochalasin-B, it is recommended to measure the Relative Population Doubling (RPD) and/or Relative Increase in Cell Count (RICC) to estimate the cytotoxic and cytostatic activity of the treatment. Moreover, other markers can be scored: cell integrity, apoptosis, necrosis, metaphase counting, proliferation index (PI), cell cycle, NPB, and NB.

The other possibility for the microscopic assessment of $\mathrm{MN}$ induction is the flow cytometry. The reliability of the flow cytometry is enhanced by two fluorescent staining methods of MNs. Both dyes are fluorescent specific. Ethidium monoazide bromide stains the chromatin of necrotic and mid/late stage apoptotic cells. After washing of cells and stripping of cytoplasmic membranes, they are incubated with SYTOX Green (RNase plus a pan-nucleic acid dye) which stain differentially the suspension of free nuclei and MNs [4].

At the same time, the usefulness of the in vivo MN assay scored by flow cytometry was tested. An immunochemical reagent, anti-CD71-FITC conjugate, together with propidium iodide were used to detect MNs in young polychromatic and normochromatic erythrocytes. In conclusion, it was found that flow cytometry can be used for the assessment of MN induction after acute and chronic exposures of rats to the aneugenic/clastogenic agents [5]. The flow cytometry method performed with Hoechst 33258 and propidium iodide is admissible for automated scoring in in vivo MN assay using rat bone marrow and peripheral blood [22]. Nowadays, automation of the MN assays with the use of imaging flow cytometry indeed represents „twenty-first century approach“ and is able to identify and automatically score binucleated cells, micronucleated binucleated cells, mono-, multinucleated cells, NPB, NB, apoptotic and necrotic cells [38].

\section{APPLICATION OF CBMN ASSAY IN AQUATIC ANIMALS}

Cytogenetic assays on aquatic organisms are essential, as humans are exposed throughout their lifetime to many xenobiotics present in both the water and aquatic food. The MN test used for genotoxic biomonitoring of chemical compounds, pesticides and environmental pollutants has proven to be the most practical tool in genotoxicological assays; various aquatic species were used $[8,20,51]$. In vivo $\mathrm{MN}$ tests performed on fish and other aquatic species erythrocytes were used as useful tools in determining the potential genotoxicity of pesticides. Increased levels of micronuclei were found in rainbow trout Oncorhynchus mykiss after amoxicillin exposure at the highest concentration tested (320 mg. $\mathrm{kg}^{-1}$ ) [2]. Another study evaluated the mutagenic potential of rotenone in the same fish and the results showed a significantly increased $\mathrm{MN}$ frequency in the four lowest concentrations tested: i. e. $0.06 ; 0.125 ; 0.187$ and $0.25 \mathrm{mg}^{-\mathrm{l}^{-1}}$ [28]. Then, the potential genotoxic effect of glyphosate formulation Roundup ${ }^{\circledR}$ [8], atrazine-based formulation Gesaprim ${ }^{\circledR}$ [7], trifluralin-based formulation Treflan $^{\circledast}$ [24], chlorpyrifos [1], malathion [25] and imidacloprid [54] were assessed in fish erythrocytes. In all, significantly elevated levels of MNs were detected.

On the other hand, atrazine as a single compound was found to be nongenotoxic, whereas atrazine-based formulation Gesaprim ${ }^{\circledast}$ showed genotoxic effects [7]. Also, the risk assessment of $\mathrm{MN}$ frequencies in flounder Platichthys flesus, herring Clupea harengus and eelpout Zoarces viviparus were investigated by $\mathrm{B}$ a r š i e n é et al. [3]. They obtained data from different regions of the Baltic Sea in the years 2001 to 2011. Their MN analysis in erythrocytes showed that there were extremely high genotoxicity risk zones in many tested regions; the highest level of MN was found in flounder.

Not only fish were used as experimental models to assess the impact of environmental pollutants on freshwater ecosystems. The genotoxic effects of many pesticides accompanied with increased $\mathrm{MN}$ frequencies were detected in lizards (Podarcis sicula) [6], tadpoles of Chinese toad Bufo gargarizans [56], tadpoles of Indian frog Euflictis cyanophlyctis [55] and Montevideo tree frog Hypsiboas pulchellus [35]. Lajm a novich et al. [26] carried out erythrocyte MN tests on tadpoles of the common toad Rhinella arenarum. They exposed them to glufosinate-ammonium 
and its commercial formulation Liberty ${ }^{\circledast}$ for 48 and $96 \mathrm{~h}$ at concentrations of $3.75 ; 7.5$ and 15 mg.1.$^{-1}$. A statistically significant increase of $\mathrm{MN}$ frequencies were detected only after $48 \mathrm{~h}$ treatment with Liberty ${ }^{\oplus}$ at the concentrations of 7.5 and $15 \mathrm{mg} . \mathrm{l}^{-1}$. In another study, an increased frequency of micronuclei was observed in the tadpoles of Hypsiboas pulchellus [34]. They were exposed to imidaclopridbased formulation Glacoxan Imida $^{\otimes}\left(12.5-37.5 \mathrm{mg} . \mathrm{l}^{-1}\right)$ for 48 and $96 \mathrm{~h}$, but the genotoxic effects were seen only at the concentration of $25 \mathrm{mg} \cdot \mathrm{l}^{-1}$ after the $96 \mathrm{~h}$ treatment.

The ambiguous results of flurochloridone-based formulations Twin Pack Gold ${ }^{\circledR}$ and Rainbow ${ }^{\circledR}$ genotoxicity were observed on tadpoles of toad Rhinella arenarum [29]. After exposure to Twin Pack Gold ${ }^{\oplus}$, the MN frequency did not differ from the negative control, regardless of the tested concentrations and both exposure time, whereas Rainbow ${ }^{\circledR}$ caused an increase in the MN frequency only after $48 \mathrm{~h}$ treatment with the lowest concentration $\left(0.71 \mathrm{mg} . \mathrm{l}^{-1}\right)$ tested. And also for the first time, a turtle Trachemys callirostris was used in the MN induction assessment [57]. This endemic species from northern Colombia was used to characterize DNA damage caused by contaminated environments.

Our water environments are dangerously polluted and the first contact with the pollutants are mainly fish, other aquatic and amphibian species. These results from the above mentioned studies indicated potential genotoxic effects of contaminants from the released and/or leaked chemical pollutants and used pesticides in agriculture near water sources. On the other hand, some studies showed inconclusive and ambiguous results, but there is still a need for further investigation using $\mathrm{MN}$ assays as a tool for genotoxicity monitoring.

\section{APPLICATION OF CBMN ASSAY IN FARM ANIMALS}

Pesticides are chemicals which help us in agriculture to control the pests, weeds or plant diseases, but on the other hand their extensive use leads in their accumulation in the environment and the possibility of potential hazards to animals' health. A broad range of in vivo and in vitro cytogenetic assays have been used for genotoxicity assessment of pesticides. The predominantly used cytogenetic assays are the $\mathrm{MN}$ assay and the chromosomal aberration test performed on different experimental models and cell lines.
Cattle and other farm animals like rabbits and chickens are mostly exposed to environmental pollutants via contaminated feed and water, which may result in the accumulation of some chemicals in the milk [13], meat and fat [27] used for primary consumption and food processing. Finally, negative health effects can be seen in animal offspring and humans after their consumption [33]. The methodology of $\mathrm{MN}$ assay performed on bovine peripheral lymphocytes has been described by Galdík ová et al. [17]. Briefly, the peripheral blood from 2 healthy bulls were cultivated for $72 \mathrm{~h}$ at $37^{\circ} \mathrm{C}$ in cultivation medium. Cytochalasin B was added $44 \mathrm{~h}$ after the initialization of the cultivation. The following time periods were used for pesticide treatments: 4, 24 and $48 \mathrm{~h}$. Then, 1000 BNMN cells were scored for the MN induction and 500 cells for the CBPI analysis.

Neonicotinoid insecticides have been widely applied and acted as selective inhibitors of nicotinic acetylcholine receptors in the central nervous system of insects leading to accumulation of acetylcholine and subsequently to death [21]. The potential genotoxic effects of the insecticide thiacloprid and thiacloprid-based formulation Calypso ${ }^{\circledR}$ was evaluated after 24 and $48 \mathrm{~h}$ exposures. The results showed no significant increase in MN frequencies after any concentration tested $\left(30,60,120,240\right.$ and $\left.480 \mu \mathrm{g} \cdot \mathrm{ml}^{-1}\right)$ [17, 18]. On the other hand, both pesticides reduced the CBPI in a dose dependent manner after $24 \mathrm{~h}$ and a prolonged time of exposure as well. To elucidate the mechanism of action, the experiments with short-time treatment were also performed [41]. Unlike the previously published results, significant induction of micronuclei were observed accompanied with the CBPI reduction. The authors assumed that micronuclei induction was a temporary process in $4 \mathrm{~h}$ treatment compared to prolonged exposures due to micronuclei elimination during the cultivation process. Moreover, higher levels of apoptotic cells, cell cycle stop in G0/ G1, recruitment of $\mathrm{p} 53$, and DNA double strand breaks were detected. Other authors evaluated the effects of the insecticides chlorpyrifos, cypermethrin and their mixture on bovine lymphocytes in vitro [16]. They found a higher incidence of $\mathrm{MN}$ and nuclear buds with a simultaneous decrease in CBPI after treatment with cypermethrin and the mixture. It is known they induce, oxidative stress, disturb synthesis of hormones and have a negative impact on reproduction.

The other group of tested pesticides represented triazole based fungicides. Their mode of action is based on ergos- 
terol synthesis inhibition via lanosterol $14-\alpha$-demethylase inhibition [9]. Finally, fungal cell permeability is disturbed and slower cell growth occurs. An epoxiconazole-fenpropimorph-based fungicide formulation Tango ${ }^{\circledR}$ Super was tested in bovine lymphocytes using concentrations of 0.5, 1.5, 3, 6 and $15 \mu \mathrm{g} \cdot \mathrm{ml}^{-1}$ for 4,24 and $48 \mathrm{~h}$ exposures. The fungicide did not induce micronuclei production, but the cell proliferation was significantly decreased [10, 42]. Moreover, it was supposed that higher levels of apoptotic cells were the result of DNA damage caused by oxidative stress damage [42]. Epoxiconazole, an active agent of Tango $^{\oplus}$, was tested also. The results were very similar to those obtained in a commercial formulation; no clastogenic/aneugenic effects but a decrease in the CBPI were observed after 24/48 h treatment [47]. Other triazole fungicide formulations, namely a tebuconazole-based fungicide Orius ${ }^{\circledast}$ $25 \mathrm{EW}$ and tebuconazole/prothioconazole-based fungicide Prosaro ${ }^{\circledR}$ were used in experiments; no significant increase in the MN frequencies but a significant decline in proliferation indices were observed $[40,46]$.

Results demonstrating the pesticide effect on micronucleus formation in sheep (in vivo or in vitro) are not so common. Tolylfluanid, a fungicide, was tested in sheep after 28-day chronic exposure [50] and in in vitro conditions [49]. In both cases, the fungicide was able to induce higher levels of MN. At the same time, no cytotoxic effect was seen. Then, the positive effect of vitamin $\mathrm{E}$ and selenium from the perspective of $\mathrm{MN}$ level reduction after carbon tetrachloride induction was observed in ovine lymphocytes [48].

Rabbits, as common small farm animals are also good bioindicators for genotoxicity assessment. Their advantages are: easy manipulation, sampling, housing and low cost compared to big animals. The effect of neonicotinoid imidacloprid was studied after oral administration for 2 to 4 months [44, 52]. Chronical exposure led to statistically significant MN induction with no changes in the CBPI. Similar results were found in rabbit lymphocytes after chronical treatment with cypermethrin, piperonylbutoxid and their mixture [53]. On the other hand, negative result in the ability to induce $\mathrm{MN}$ formation in bone marrow erythrocytes was obtained after bendiocarbamate administration after a 90-day chronical administration [36]. Simultaneously depression in bone marrow proliferation was seen.

Finally, the studies performed on poultry (chickens, ducks...etc.) were very rare. G i r i et al. [19] studied the ef- fects of malathion on chicks. They detected significant MN elevation not only in the bone marrow $\left(2.5,5,10\right.$ mg. $\left.\mathrm{kg}^{-1}\right)$ but also in the peripheral cells ( 5 and $10 \mathrm{mg} \cdot \mathrm{kg}^{-1}$ ). Higher numbers of MN were also seen in broiler chicken blood erythrocytes after cypermethrin administration [43]. The $\mathrm{MN}$ reduction was seen after simultaneous treatment with vitamin $\mathrm{E}$ and selenium.

\section{CONCLUSIONS}

The micronucleus assays (in vivo or in vitro) together with chromosomal aberration tests are some of the officially approved tests by OECD for chromosomal damage testing. Our review informs briefly about the actual status and usage of $\mathrm{MN}$ assay in genotoxicity monitoring in aquatic environments and with farm animals. Testing the aquatic organisms is the best option of how to confirm or deny the presence of harmful chemical agents in the water and surrounding biotope because feed and water are the main sources of environmental exposure to farm animals. According to these results, we can conclude that the MN assay is a suitable method because of the simultaneous detection of aneugenic and clastogenic effects of chemicals. Moreover, in many cases a cytotoxic effect (reduction of CBPI) was observed even though there were no $\mathrm{MN}$ induction or vice versa. The use of CBMN cytome assay in peripheral lymphocytes provides an opportunity to study genotoxicity and cytotoxicity within in vitro and also ex vivo, which is important for modelling and predicting the in vivo genotoxic effects to chemical agents on humans.

\section{ACKNOWLEDGEMENTS}

This study was supported by the Slovak Scientific Agency VEGA [project 1/0242/19] and IGA [1/2019]: Assessment of genotoxic and cytotoxic effect of acetamipride insecticide in cell cultures.

\section{REFERENCES}

1. Ali, D., Nagpure, N. S., Kumar, S., Kumar, R., Kushwaha, B., 2008: Genotoxicity assessment of acute exposure of chlorpyrifos to freshwater fish Channa punctatus (Bloch) using 
micronucleus assay and alkaline single-cell gel electrophoresis. Chemosphere, 71, 10, 1823-1831. DOI: 10.1016/j.chemosphere.2008.02.007.

2. Anlas, C., Ustuner, O., 2016: Genotoxic assessment of amoxicillin on rainbow trout (Oncorhynchus mykiss) by comet assay and micronucleus test. Fresen. Envinron. Bull., 25, 12, 5358-5364.

3. Baršiené, J., Rybakovas, A., Lang, T., Grygiel, W., Adreikénaité, L., Michailovas, A., 2012: Risk of environmental genotoxicity in the Baltic sea over the period of 2009-2011 assessed by micronuclei frequencies in blood erythrocytes of flounder (Platichthys flesus), herring (Clupea harengus) and eelpout (Zoarces viviparus). Mar. Environ. Res., 77, 35-42. DOI: 10.1016/j.marenvres.2012.01.004.

4. Bryce, S. M., Bemis, J. C., Avlasevich, S. L., Dertinger, S. D., 2007: In vitro micronucleus assay scored by flow cytometry provides a comprehensive evaluation of cytogenetic damage and cytotoxicity. Mutat. Res./Gen. Tox. En., 630, 1-2, 78-91. DOI: 10.1016/j.mrgentox.2007.03.002.

5. Cammerer, Z., Elhajouji, A., Suter, W., 2007: In vivo micronucleus test with flow cytometry after acute and chronic exposures of rats to chemicals. Mutat. Res./Gen. Tox. En., 626, 1-2, 26-33. DOI: 10.1016/j.mrgentox.2006.08.004.

6. Capriglione, T., de Iorio, S., Gay, F., Capaldo, A., Vaccaro, M. C., Morescalchi, M. A., et al., 2011: Genotoxic effects of the fungicide thiophanate-methyl on Podarcis sicula assessed by micronucleus test, comet assay and chromosome analysis. Ecotoxicology, 20, 4, 885-891. DOI: 10.1007/s10646-0110655-8.

7. Cavas, T., 2011: In vivo genotoxicity evaluation of atrazine and atrazine-based herbicide on fish Carassius auratus using the micronucleus test and the comet assay. Food Chem. Toxicol., 49, 6, 1431-1435. DOI: 10.1016/j.fct.2011.03.038.

8. Cavas, T., Konen, S., 2007: Detection of cytogenetic and DNA damage in peripheral erythrocytes of goldfish (Carassius auratus) exposed to a glyphosate formulation using the micronucleus test and the comet assay. Mutagenesis, 22, 4, 263-268. DOI: 10.1093/mutage/gem012.

9. Chambers, J. E., Greim, H., Kendall, R. J., Segner, H., Sharpe, R. M., Van Der Kraak, G., 2014: Human and ecological risk assessment of a crop protection chemical: a case study with the azole fungicide epoxiconazole. Crit. Rev. Toxicol., 44, 2, 176-210. DOI: 10.3109/10408444.2013.855163.

10. Drážovská, M., Šiviková, K., Holečková, B., Dianovský, J., Galdíková, M., Schwarzbacherová, V., 2016: Evaluation of potential genotoxic/cytotoxic effects induced by epoxicon- azole and fenpropimorph-based fungicide in bovine lymphocytes in vitro. J. Environ. Sci. Health B, 51, 11, 769-776. DOI: 10.1080/03601234.2016.1198643.

11. Erenpreisa, J., Huna, A., Salmina, K., Jackson, T. R., Cragg, M. S., 2012: Macroautophagy-aided elimination of chromatin: sorting of waste, sorting of fate? Autophagy, 8, 18771881. DOI: $10.4161 /$ auto.21610.

12. Evans, H. J., Neary, G. J., Williamson, F. S., 1959: The relative biological efficiency of single dosses of fast neutrons and gamma-rays on Vicia fava roots and the effect of oxygen. Part II. Chromosome damage: the production of micronuclei. Int. J. Radiat. Biol. Relat. Stud. Phys. Chem. Med., 1, 216-229. DOI: 10.1080/09553005914550311.

13. Fedrizzi, G., Altafini, A., Armorini, S., Al-Qudah, K. M., Roncada, P., 2019: LC-MS/MS analysis of five neonicotinoid pesticides in sheep and cow milk samples collected in Jordan valley. Bull. Environ. Contam. Toxicol., 102, 347-352. DOI: 10.1007/s00128-019-02555-8.

14. Fenech, M., 2007: Cytokinesis-block micronucleus cytome assay. Nat. Protoc., 2, 5, 1084-1104. DOI: 10.1038/nprot. 2007.77.

15. Fenech, M., Chang, W. P., Kirsch-Volders, M., Holland, N., Bonassi, S., Zeiger, E., 2003: HUMN project: detailed description of the scoring criteria for the cytokinesis-block micronucleus assay using isolated human lymphocyte cultures. Mutat. Res. /Gen. Tox. En., 534, 1-2, 65-75. DOI: 10.1016/ S1383-5718(02)00249-8.

16. Ferré, D. M., Luduena, H. R., Romano, R. R., Gorla, N. B. M., 2020: Evaluation of the genotoxic potential of cypermethrin, chlorpyrifos and their subsequent mixture, on cultured bovine lymphocytes. Chemosphere, 243, 125341, DOI: 10.1016/j.chemosphere.2019.125341.

17. Galdíková, M., Holečková, B., Šiviková, K., Schwarzbacherová, V., Koleničová, S., 2019: Evaluation the genotoxic damage in bovine whole blood cells in vitro after exposure to thiacloprid. Toxicol. In Vitro, 61, 104616. DOI: 10.1016/j. tiv.2019.104616.

18. Galdíková, M., Šiviková, K., Holečková, B., Dianovský, J., Drážovská, M., Schwarzbacherová, V., 2015: The effect of thiacloprid formulation on DNA/chromosome damage and changes in GST activity in bovine peripheral lymphocytes. J. Environ. Sci. Health B, 50, 10, 698-707. DOI: 10.1080/03601234.2015.1048102.

19. Giri, S., Sharma, G. D., Giri, A., Prasad, S. B., 2002: Genotoxic effect of malathion in chick in vivo micronucleus assay. Cytologia, 67, 1, 53-59. DOI: 10.1508/cytologia.67.53. 
20. Grisolia, C. K., 2002: A comparison between mouse and fish micronucleus test using cyclophosphamide, mitomycin $\mathrm{C}$ and various pesticides. Mutat. Res./Gen. Tox. En., 518, 2, 145-150. DOI: 10.1016/s1383-5718(02)00086-4.

21. Han, W. C., Tian, Y., Shen, X. M., 2018: Human exposure to neonicotinoid insecticides and the evaluation of their potential toxicity: An overview. Chemosphere, 192, 59-65. DOI: 10.1016/j.chemosphere.2017.10.149.

22. Harada, A., Matsuzaki, K., Takeiri, A., Tanaka, K., Mishima, M., 2013: Fluorescent dye-based simple staining for in vivo micronucleus test with flow cytometer. Mutat. Res./Gen. Tox. En., 751, 2, 85-90. DOI:10.1016/j.mrgentox.2012.12.006.

23. Hintzsche, H., Hemmann, U., Poth, A., Utesch, D., Lott, J., Stopper, J., et al., 2017: Fate of micronuclei and micronucleated cells. Mutat. Res./Rev. Mutat., 771, 85-98. DOI: 10.1016/j.mrrev.2017.02.002.

24. Konen, S., Cavas, T., 2008: Genotoxicity testing of the herbicide trifluralin and its commercial formulation Treflan using the piscine micronucleus test. Environ. Mol. Mutagen., 49, 6, 434-438. DOI: 10.1002/em.20401.

25. Kumar, R., Nagpure, R. S., Kushwaha, B., Srivastava, S. K., Lakra, W. S., 2010: Investigation of the genotoxicity of malathion to freshwater teleost fish Channa punctatus (Bloch) using the micronucleus test and comet assay. Arch. Environ. Con. Tox., 58, 1, 123-130. DOI: 10.1007/s00244-009-9354-3.

26. Lajmanovich, R. C., Cabagna-Zenklusen, M. C., Attademo, A. M., Junges, C. M., Peltzer, P. M., Bassó, A., et al., 2014: Induction of micronuclei and nuclear abnormalities in tadpoles of the common toad (Rhinella arenarum) treated with the herbicides Liberty ${ }^{\circ}$ and glufosinate-ammonium. Mutat. Res./Genet. Toxicol. Environ. Mutagen., 769, 7-12. DOI: 10.1016/j.mrgentox.2014.04.009.

27. MacLachlan, D. J., Bhula, R., 2009: Transfer of lipid-soluble pesticides from contaminated feed to livestock, and residue management. Anim. Feed Sci. Technol., 149, 3-4, 307-321. DOI: 10.1016/j.anifeedsci.2008.06.007.

28. Melo, K. M., Grisolia, C. K., Pieczarka, J. C., de Souza, L. R., de Souza Filho, J., Nagamachi, C. Y., 2014: FISH in micronucleus test demonstrates aneugenic action of rotenone in a common freshwater fish species, Nile tilapia (Oreochromis niloticus). Mutagenesis, 29, 3, 215-219. DOI:10.1093/mutage/geu005.

29. Nikoloff, N., Natale, G. S., Marino, D., Soloneski, S., Larramendy, M. L., 2014: Flurochloridone-based herbicides induced genotoxicity effects on Rhinella arenarum tadpoles
(Anura: Bufonidae). Ecotoxicol. Environ. Safety, 100, 275281. DOI: 10.1016/j.ecoenv.2013.10.021.

30. Nito, S., Ariyuki, F., Okinawa, A., 1988: Spontaneous expulsion of micronuclei by enucleation in the micronucleus assay. Mutat. Res. Lett., 207, 3-4, 185-192. DOI: 10.1016/01657992(88)90085-1.

31. OECD, 2016a: Guideline for the Testing of Chemicals, Test No. 474: Mammalian Erythrocyte Micronucleus Test. OECD Publishing, 1-21.

32. OECD, 2016b: Guideline for the Testing of Chemicals, Test No. 487: In Vitro Mammalian Cell Micronucleus Test. OECD Publishing, 1-29.

33. Pardío, V., Martínez, D., Flores, A., Romero, D., Suárez, V., López, K., et al., 2012: Human health risk of dietary intake of organochlorine pesticide residues in bovine meat and tissues from Veracruz, México. Food Chem., 135, 3, 1873-1893. DOI: 10.1016/j.foodchem.2012.06.079.

34. Pérez-Iglesias, J. M., de Arcaute, C. R., Nikoloff, N., Dury, L., Soloneski, S., Natale, G. S., et al., 2014: The genotoxic effects of the imidacloprid-based insecticide formulation Glacoxan Imida on Montevideo tree frog Hypsiboas pulchellus tadpoles (Anura, Hylidae). Ecotoxicol. Environ. Safety, 104, 120-126. DOI: 10.1016/j.ecoenv.2014.03.002.

35. Pérez-Iglesias, J. M., Soloneski, S., Nikoloff, N., Natale, G. S., Larramendy, M. L., 2015: Toxic and genotoxic effects of the imazethapyr-based herbicide formulation Pivot Hs on montevideo tree frog Hypsiboas pulchellus tadpoles (Anura, Hylidae). Ecotoxicol. Environ. Safety, 119, 15-24. DOI: 10.1016/j.ecoenv.2015.04.045.

36. Piešová, E., Valočíková, I., 2005: The activity of bendiocarbamate in the rabbit bone marrow micronucleus assay. Folia Vet., 49, 1, 24-26.

37. Rello-Varona, S., Lissa, D., Shen, S., Niso-Santano, M., Senovilla, L., Marino, G., et al., 2012: Autophagic removal of micronuclei. Cell Cycle, 11, 170-176. DOI: 10.4161/cc.11.1. 18564.

38. Rodrigues, M. A., Beaton-Green, L. A., Wilkins, R. C., Fenech, M. F., 2018: The potential for complete automated scoring of the cytokinesis block micronucleus cytome assay using imaging flow cytometry. Mutat. Res./Genet. Toxicol. Environ. Mutagen., 836, part A, 53-64. DOI: 10.1016/j. mrgentox.2018.05.003.

39. Schriever-Schwemmer, G., Kliesch, U., Adler, I. D., 1997: Extruded micronuclei induced by colchicine or acrylamide contain mostly lagging chromosomes identified in paintbrush smears by minor and major mouse DNA probes. $\mathrm{Mu}$ tagenesis, 12, 4, 201-207. DOI: 10.1093/mutage/12.4.201. 
40. Schwarzbacherová, V., Šiviková, K., Drážovská, M., Dianovský, J., 2015: Evaluation of DNA damage and cytotoxicity induced by triazole fungicide in cultured bovine lymphocytes. Caryologia, 68, 3, 233-238. DOI: 10.1080/00087114. 2015.1032613.

41. Schwarzbacherová, V., Wnuk, M., Deregowska, A., Holečková, B., Lewinska, A., 2019: In vitro exposure to thiacloprid-based insecticide formulation promotes oxidative stress, apoptosis and genetic instability in bovine lymphocytes. Toxicol. In Vitro, 61, 104654. DOI: 10.1016/j.tiv.2019.104654.

42. Schwarzbacherová, V., Wnuk, M., Lewinska, A., Potocki, L., Zebrowski, J., Koziorowski, M., et al., 2017: Evaluation of cytotoxic and genotoxic activity of fungicide formulation Tango Super in bovine lymphocytes. Environ. Pollut., 220, 255-263. DOI: 10.1016/j.envpol.2016.09.057.

43. Sharaf, S., Khan, A., Khan, M. Z., Alsam, F., Saleemi, M. K., Mahmood, F., 2010: Clinico-hematological and micronuclear changes induced by cypermethrin in broiler chicks: Their attenuation with vitamin $\mathrm{E}$ and selenium. Exp. Toxicol. Pathol., 62, 4, 333-341. DOI: 10.1016/j.etp.2009.05.002.

44. Stivaktatis, P. D., Kavvalakis, M. P., Tzatzarakis, M. N., Alegakis, A. K., Panagiotakis, M. N., Fragkiadaki, P., et al. 2016: Long-term exposure of rabbits to imidaclorpid as quantified in blood induces genotoxic effect. Chemosphere, 148, 108-113. DOI: 10.1016/j.chemosphere.2016.01.040.

45. Surrallés, J., Xamena, N., Creus, A., Catalán, J., Norppa, H., Marcos, R., 1995: Induction of micronuclei by five pyrethroid insecticides in whole-blood and isolated human lymphocyte cultures. Mutat. Res./Genet. Toxicol., 341, 3, 169184. DOI: 10.1016/0165-1218(95)90007-1.

46. Šiviková, K., Dianovský, J., Holečková, B., Galdíková, M., Kolesárová, V., 2013: Assessment of cytogenetic damage in bovine peripheral lymphocytes exposed to in vitro tebuconazole-based fungicide. Chemosphere, 92, 555-562. DOI: 10. 1016/j.chemosphere.2013.04.001.

47. Šiviková, K., Holečková, B., Schwarzbacherová, V., Galdíková, M., Dianovský, J. 2018: Potential chromosome damage, cell-cycle kinetics/and apoptosis induced by epoxiconazole in bovine peripheral lymphocytes in vitro. Chemosphere, 193, 82-88. DOI: 10.1016/j.chemosphere.2017.11.008.

48. Šiviková, K., Piešová, E., Dianovský, J., 2001: The protection of vitamin $\mathrm{E}$ and selenium against carbon tetrachlorideinduced genotoxicity in ovine peripheral blood lymphocytes. Mutat. Res., 494, 1-2, 135-142. DOI: 10.1016/S13835718(01)00190-5.
49. Šutiaková, I., Kovalkovičová, N., Legáth, J., Šutiak, V., 2010: Micronucleus frequency in sheep lymphocytes after in vitro exposure to fungicide tolylfluanid. J. Environ. Sci. Health B, 45, 606-611. DOI: 10.1080/03601234.2010.502401.

50. Šutiaková, I., Kovalkovičová, N., Pistl, J., Novotný, J., Legáth, J., Kováč, G., et al., 2006: Chromosomal aberrations and frequency of micronuclei in sheep subchronically exposed to the fungicide Euparen Multi (tolylfluanid). Ecotoxicol. Environ. Safety, 64, 3, 312-320. DOI: 10.1016/j. ecoenv.2005.04.011.

51. Udroiu, I., 2006: Feasibility of conducting the micronucleus test in circulating erythrocytes from different mammalian species: an anatomical perspective. Environ. Mol. Mutagen., 47, 643-646. DOI: 10.1002/em.20258.

52. Vardavas, A. I., Ozcagli, E., Fragkiadaki, P., Stivaktatis, P. D., Tzatzarakis, M. N., Alegakis, A. K., et al., 2018: The metabolism of imidacloprid by aldehyde oxidase contributes to its clastogenic effect in New Zealand rabbits. Mutat. Res., 829-830, 26-32. DOI: 10.1016/j.mrgentox.2018.03.002.

53. Vardavas, A. I., Stivaktatis, P. D., Tzatzarakis, M. N., Fragkiadaki, P., Vasilaki, F., Tzardi, M., et al., 2016: Long-term exposure to cypermethrin and piperonyl butoxide cause liver and kidney inflammation and induce genotoxicity in New Zealand white male rabbits. Food Chem. Toxicol., 94, 250-259. DOI: $10.1016 /$ j.fct.2016.06.016.

54. Xia, X., Xia, X., Huo, W., Dong, H., Zhang, L., Chang, Z., 2016: Toxic effects of imidacloprid on adult loach (Misgurnus anguillicaudatus). Environ. Toxicol. Pharmacol., 45, 132-139. DOI: 10.1016/j.etap.2016.05.030.

55. Yadav, S. S., Giri, S., Singha, U., Boro, F., Giri, A., 2013: Toxic and genotoxic effects of Roundup on tadpoles of the Indian skittering frog (Euflictis cyanophlyctis) in the presence and absence of predator stress. Aquat. Toxicol., 132-133, 1-8. DOI: 10.1016/j.aquatox.2013.01.016.

56. Yin, X., Zhu, G., Li, X. B., Liu, S., 2009: Genotoxicity evaluation of chlorpyrifos to amphibian Chinese toad (Amphibian: Anura) by Comet assay and Micronucleus test. Mutat. Res., 680, 1-2, 2-6. DOI: 10.1016/j.mrgentox.2009.05.018.

57. Zapata, L. M., Bock, B. C., Orozco, L. Y., Palacio, J. A., 2016: Application of the micronucleus test and comet assay in Trachemys callirostris erythrocytes as a model for in situ genotoxic monitoring. Ecotoxicol. Environ. Safety, 127, 108-116, DOI: 10.1016/j.ecoenv.2016.01.016.

Received February 17, 2020

Accepted April 6, 2020 